International Journal of Social Science And Human Research

ISSN(print): 2644-0679, ISSN(online): 2644-0695

Volume 04 Issue 12 December 2021

DOI: $10.47191 /$ ijsshr/v4-i12-55, Impact factor-5.586

Page No: 3858-3869

\title{
The Role of Psychology Prevention in Controlling Student Victimization in Terms of Accounting Method (A Case Study of Sari)
}

\author{
Peyman Salehi' ${ }^{1}$ Maedeh Fallah ${ }^{2}$, Shaghayegh Maleki Hajikola ${ }^{3}$, Amihossein Dadmehr ${ }^{4}$, \\ Masood Kamali ${ }^{5}$, Kimia Mohseni Chamazkoti ${ }^{6}$ \\ ${ }^{1,2}$ Faculty of Law, Farvardin University, Qaemshahr, Iran \\ ${ }^{4,6}$ Faculty of Psychology, Farvardin University, Qaemshahr, Iran \\ ${ }^{3,5}$ Faculty of Accounting, Farvardin University, Qaemshahr, Iran
}

\begin{abstract}
With its negative psychological, economic, and social effects, student delinquency is one of Iran's most critical social issues; Iran has a young population in terms of population structure. The purpose of this article is not to search for the causes of studentdelinquency, in cases such as theft, vandalism and violence, in the whole of Iran, but to focus on the city of Sari to conduct such studies in other major cities, to comment on the community or Provide thighs. This study used a combined theoretical framework (general theory of crime) consisting of social connection and self-control theories. The findings of this study show that adolescents with poor self-control have poor social bonds and commit more crimes.
\end{abstract}

KEYWORDS: studentdelinquency, social bonding, self-control, occupation and attachment.

\section{INTRODUCTION}

studentdelinquency is unusual behaviour and a form of social deviance and the spread of that life. Endangers the social. For this reason, it has attracted the attention of researchers (sociologists, criminologists and psychologists). There are two questions in this discussion: Who is a teenager? And who is the culprit? In answering the first question, the age criterion is mainly used. In most countries, studentdelinquency laws set an age limit. In the United States, this age range varies from state to state. In Europe, this difference is also seen; For example, the studentdiagnosis criterion is 16 years in Belgium and 21 years in Sweden. In Asia, it varies from 15 years in some countries, such as Sri Lanka, Lebanon, and India, to 20 years. The term delinquency is broadly used, but in sociological terms,some adolescents neglect accepted standards of behaviour in a given society. In this article, abnormal and immoral behaviours of adolescents aged 12 to 18 years. The city of Sari, especially behaviours such as theft, destruction and violence against others, has been studied[1].

Student delinquency, with its negative effects, in two ways, is one of the most critical social issues in Iranian society is considered. First, because adolescents are in puberty and socialization, it is possible to improve and educate them. There are no reliable statistics on delinquency in Iran, but the available statistics show its growth in recent years[2]. The report of the Iranian Prisons Organization shows that the number of people under the age of 18 who were arrested in June 1977, 1978 and 1979 and handed over to prisons or correctional centres is as follows: In June 1977, a total of 3,722 people under the age of 18 were arrested, a percentage of them were girls[3]. In 1978, the number of people detained under 18 was 3,894. Second, Iranian society is a country with a young population in terms of population structure. Twelvemillion people, about 20 percent of the total population, and the estimated population of 12 to 18 years in Mazandaran province in 2004 is 358960 indicates people (population estimate of Mazandaran province until 2021, Deputy of Statistics of the Provincial Management Organization). The total population of the province this year is 2492325 people. Based on these estimates, the adolescent population aged 12 to 18 years, constitutes $14 \%$ of the total population of the province in 2004.

Delinquency among this population worries the authorities and worries most of the families. For example, during the study of studentdelinquency in Sari, parents expressed their concern about the situation of their adolescent students in public weddings, family counselling centres and observed many cases of studentdelinquency in the streets of Sari and often on the way to school (such as We were faced with ringing the doorbell and car alarms, breaking windows, beatings, obscenities, vandalism of public vehicles). The importance of this study can be traced back to Anthony Giddens, who considers delinquent studies to be one of the fascinating tasks in sociology[4]. 


\section{The Role of Psychology Prevention in Controlling Student Victimization in Terms of Accounting Method (A Case Study of Sari)}

\section{LITERATURE REVIEW}

Most of the studies in social sciences to social pathology research belong. For about four decades, studies of social pathology in general and studentdelinquency, in particular, have been common in our country and have been done in both theoretical and field forms. One of the problems of completed projects is the lack of a secure link between the research topics and the topics. Some have not taken the issue of hypothesis seriously or are methodologically ambiguous[5]. Among the numerous researches, only two studies are mentioned, which are somewhat close to the purpose of this research and have been done based on the school of control.

Assessing the effect of internal and external factors of the family on youth delinquency is the title of a project conducted in 1992 among youth arrested as criminals in Tehran. A combined theory of the two social control theories is the differential link between Sutherland and Kursi: out of 140 boys in the Correctional Centre and 15 girls in Evin Prison who were under 18 and arrested in 1992, 90 boys and girls were interviewed in an organized manner. Four dependent variables and 81 independent variables were measured. Statistical methods including multivariate regression analysis, logistic regression and factor analysis show that three factors affect the severity of delinquency: beliefs and attitudes, adolescents' dependence on family and relationship with delinquents - the more robust the adolescents' reliance on the family, the lower the severity of the offence. Religious beliefs are the deterrent to delinquency, and close association with offenders leads the adolescent to delinquency[6].

In 2001, another study entitled "Study of factors affecting the behavioural abnormalities of students in Lorestan province" was conducted. The study's statistical population was 975 male and female students of different fields of study in three cities of Khorram Abad, Noorabad and Boroujerd were selected using multi-stage cluster sampling. The researcher has used Gat Fredson's theory and Travis Hirsch's theory to select the variables. Some of the leading hypotheses are:

- The rate of behavioural abnormalities among students whose fathers are unemployed is higher than students whose fathers are employed?

- The more students are connected with their mothers. The fewer behavioural abnormalities are between them.

The more positive the students' perception, the more behavioural abnormalities there are fewer.

In this study, the abnormal behaviours of students in school and out of school are examined separately. Findings indicate that having relationships in the family and school environment, perception of the student himself, perception of family income, father's job, perception of school order, success in school work and gender as influential factors in students' behavioural abnormalities in school and some variables such as academic achievement, gender and relationship with mother are more critical in behavioural abnormalities outside of school. The rate of behavioural abnormalities in $30 \%$ of students is higher than average. Students whose parents are unemployed or retired have the highest percentage of abnormalities. Those whose father's job is a sciencespecialist have the lowest rate - the more positive the student's self-concept, the lower the student behavioural abnormalities. There is an inverse relationship between satisfaction with school order and the extent of students' behavioural abnormalities in and out of school. Another hypothesis that has been proven is that there is an inverse relationship between a student's bond with his mother and his behavioural abnormalities. Another finding of this study is a significant relationship between behavioural abnormalities in school and out of school[7].

\section{THEORETICAL FRAMEWORK}

The issue of youth delinquency has been studied from different sociological paradigms such as structuralism, social process and conflict. Each of these paradigms considers specific factors as the cause of the spread of delinquency. In this study (as will be explained), a combined perspective is used to describeyouth delinquency in the city of Sari. From a structuralism point of view, economic and social forces lead the inhabitants of lower social areas to engage in criminal behaviour patterns. Social disorder in the lower urban areas and the poor and unsupervised adolescent gangs are the most critical social problems. Many social structure theorists emphasize the relatively violent behaviours of the student. They underline that social forces have a more significant impact on adolescents[8].

This effect continues throughout life. Structuralisms say that people living in unstable social conditions tend to behave similarly. Because crime rates are lower in urban areas than in middle ones, social class should affect the behaviour. They do not explain but see delinquency as one of the social process theories that are a function of the socialization of individuals, focusing on the interaction of individuals with different organizations, institutions, and social processes[9]. Positive and supportive, one can play one's roles well in society, but if these relationships are destructive, achieving the desired success is impossible, and delinquent solutions become practical alternatives. Depending on their race, class, or gender, they are prone to delinquency or criminality. Although lower class members may face more significant pressures from poverty, racism, poor schooling, and broken family life, these pressures can be exerted through positive relationships. Neutralize peer support, family support, and academic achievement. Conversely, even the wealthiest members of society may engage in antisocial behaviour, provided that their life experiences are unbearable or destructive[10].

One of the essential theories of control is the theory of social connection. This theory is based on Travis Hirsch. He published the book Causes of Crime in 1969. The main question is why, with so much opportunity and pressure to commit a crime, most of us 


\section{The Role of Psychology Prevention in Controlling Student Victimization in Terms of Accounting Method (A Case Study of Sari)}

follow the law most of the time. The basic concept of Hirsch control theory is the connection of individuals to society. Hirsch hypothesizes that all potential individuals break the law, but most are controlled; Because they are afraid that illegal behaviours will damage their relationships with their friends, family, neighbours, teachers and employers. Without these social ties or relationships and sensitivity to the interests of others, one is free to engage in delinquent activities. Hirsch does not view society as a competing subculture with a unique value system. Most people are aware of the legal and moral standards that govern them. [11].

In his view, there is a relationship between the connection with the social system and the belief in moral legitimacy. The individual's ideas are also affected by connecting with the school, family and society[12]. "As this bond weakens, so does the intensity of beliefs. One's beliefs begin with one bond with parents and increase through bonding with the school and the community."

Hirsch argues that a person's social connection connects him to society, and four elements are: attachment, commitment, occupation and belief.

Attachment: The person has psychosis and loses the ability to communicate with the world cohesively. So the acceptance of social norms and the spread of social consciousness is based on attachment and being cared for by other human beings. Hirsch considers parents, friends, and the school as critical social institutions through which a person must maintain ties. Among these, attachment to parents is one of the most important. Even if a family is broken up by divorce or separation, a student must maintain a strong passionfor one or both of them. Without this attachment, other people are unlikely to respect this person[13].

Commitment: Includes time, energy, and effort spent on any routine activity such as training or saving money for the future. If people firmly commit to the commonplace, they are less likely to engage in actions that jeopardize their position. Conversely, a lack of commitment to conventional values can signify a situation in which risky behaviour such as crime replaces sensible behaviour [14].

Occupation: Too much to do with traditional activities, little time left for illegal activities it leaves. Hirsch believes that involvement in school, recreation and family deprives individuals of the potential for delinquent behaviour. On the other hand, unemployment tends to lead to greedy behaviour[15].

Belief: People in similar social contexts share a common moral belief. They may be loyal to such shared values and sensitivity, remain loyal to the rights, and admire legal practices. If these beliefs are destroyed or weakened, individuals are more likely to engage in illegal anti-social activities[16].

Hirsch also believes that the interaction of elements of social bonding helps control subsequent behaviours; for example, people who feel related or sensitive to their parents and friends are more likely to be drawn to legitimate goals. On the other hand, a person who does not accept such a social relationship is more likely to be inattentive to conventional goals[17].

Also, people who are more committed to conventional practices or beliefs are more likely to be drawn to activities. They are weaker and more likely to be abused - contradictory theories, not socialization processes or peer groups and subcultural patterns. Conflicts explain crime within economic and social contexts express the relationship between social class, crime and social control. Conflict theories view crime as a consequence of social struggle. They argue that the different distribution of power in pluralistic societies allows some groups with sufficient force to pass laws and regulations to their advantage and to the detriment of rival groups (Reed, In such a context, delinquency theories such as social structure and the social process cannot be explained from an integrated perspective, because crime is a complex concept and involves the perception of the perpetrator, the victim, and the whole of the crime. It is one of the dominant theories, which is the theory of social control. And combines everyday activities and ideas of rational choice. They reject traditional theories of crime. From this point of view, crime is logical, reasonable, and predictable. In other words, whatever The risk of crime is higher, "The crime rate is declining" [18].

According to Gott Fredson and Hirsch, the tendency to commit a crime depends on the level of "restraint". People with low selfcontrol, the six main characteristics of this view of "low self-control". They are different. First, they seek immediate satisfaction with an attitude here and now. In comparison, high self-control is associated with the ability to delay pleasure. Second, people with low self-esteem use easy methods to satisfy their desires. Crime provides them with money without the hassle of fast sex and without preliminaries (foreplay). Third, they meet their needs by committing a crime that involves risk, agility, excitement, and deception. Compared to people with high self-control, they tend to be cautious, thinking and reasoning. Fourth, people with low self-control have little stability in their lives. They do not have friendships or family life due to crimes, strength in work or profession. To commit a crime does not require long-term ability and planning that requires patience. Therefore, people with low self-control do not seek intellectual and practical skills. Fifth, people with low self-control are self-centred, indifferent, and insensitive to the suffering and needs of others. Finally, people with low self-control have little tolerance for failure and respond physically to conditions rather than semantically and linguistically. These people are more prone to engaging in delinquent activities throughout their lives than people with high self-control[19].

Low restraint interacts with crime opportunities. When there is an opportunity to commit a crime, a person with high self-control is not prone to commit this act, but a person with low self-control is prone to give up. The authorsbelieve ina general theory that 


\section{The Role of Psychology Prevention in Controlling Student Victimization in Terms of Accounting Method (A Case Study of Sari)}

explains all crimes at all times. They think that crime causes Quick and easy gratification. A person behaves crookedly, commits an offence, seeks quick gratification, has short-term goals in life, and is more inclined to consume alcohol and cigarettes. Socialization of the individual was found in childhood. From this point of view, the leading causes of poor self-control are inappropriate parenting practices. Poor self-control develops in early childhood and remains constant throughout adolescence. Parents who are unable or unwilling to control their student's behaviour or who are opposed to maintaining their student's behaviour, by recognizing the student's deviant behaviour, punish them, and this punishment causes the student to lose their self-control[20].

\section{THE THEORETICAL FRAMEWORK OF RESEARCH}

The reason for the combined theory of Hirsch and Gat Fredson is the theoretical tendency of this research. Hirsch has been experimentally and theoretically evaluating his approach for three decades. Finally, in 1990 he proposed a new idea called the General Theory of Crime, claiming that it can be explained. It has all kinds of crimes and atrocities at all times and places. His research is the source of much research on delinquency. Second, the general theory of crime is focused on adolescents, and the current research focuses on adolescents in Sari; It is appropriate. Third, this theory has not been used in experiments related to youth delinquency in Iran and has not been tested experimentally[21].

\section{RESEARCH METHOD}

The survey often begins with identifying individuals who have studied one method of this research based on the scientific approach of the representative and representative of the case group (sample) and the design of questions that should be asked of them ". In this type of study, respondents to questions answered by their survey method indicate the type, amount and quality of their participation in different forms of delinquency. This type of study determines the prevalence of recorded delinquency. Estimating the number of unknown offenders is usually of particular importance. It is mainly used for youth delinquency, and student populations, especially in schools, have done this.

The statistical population of second and third-year male high school students in Sari and two are in the 2003-2004 academic year. After reducing the number of adult school students, the statistical population of this study is about 12,300 people, $20 \%$ of whom are in non-profit schools and $80 \%$ in public schools. The sample size of this study was determined based on previous studies in schools and according to the time and budget of the research and the fact that it was not possible to refer more people by the researcher in the short time available, 400 people and this number with an additional $10 \%$ due to potential fuel and answers. Incomplete receipts increased to 440 people, of which 35 incomplete questionnaires were removed, and 405 questionnaires remained complete. Therefore, the actual sample size was 405 people.

Society statistically was divided into two categories according to the two districts of education. The sampling method of this research is three-stage cluster sampling. In the first stage, schools are based on classes' government, and non-government and theoretical, technical and professional being were randomly selected. Then, in each category of schools, the academic, technical and vocational secondary schools were classified into three categories according to the type of school. After that, the schools were divided into governmental and non-profit. The second stage of sampling was a random selection of classes from selected schools, and the third stage was a random selection of students in each category.

The main concepts of the research are restraint, social bonding, attachment, adolescent delinquency, belief, occupation, commitment. Based on the theoretical framework of this paper, the hypotheses under study are: One, restraint is inversely related to youth delinquency. Second, social bonding is inversely associated with youth delinquency. Third, restraint is directly related to social bonding. Nineteen items measure this variable. The attachment variable means that the person is sensitive to others. Attachment is a visible 11 dimension. The variable of commitment is a type of investment that a person has in the contracts of society and is the degree of risk that he feels in violation of contractual social behaviours (such as losing a job). The variable of busyness is related to high involvement in routine activities such as participation in-home activities, extracurricular activities, and membership in sports clubs (ibid.).Assessment of this concept is dedicated. The belief variable means that the individual accepts and respects society's contractual norms and laws. Three items are used to measure belief.

Table 1. Variables of social bonding

\begin{tabular}{|c|c|c|c|}
\hline Variable & \multicolumn{2}{|l|}{ Indicator } & Item \\
\hline \multirow{2}{*}{$\begin{array}{l}\frac{\pi}{U} \\
0 \\
\tilde{D}\end{array}$} & \multirow[b]{2}{*}{ Attachment } & \multirow{2}{*}{$\begin{array}{l}\text { Attachment To The } \\
\text { Teacher }\end{array}$} & I Often Talk To My Teacher About My Problems. \\
\hline & & & $\begin{array}{l}\text { The Teacher's Opinion On A Particular Issue Is Very Important To } \\
\text { Me. }\end{array}$ \\
\hline
\end{tabular}


The Role of Psychology Prevention in Controlling Student Victimization in Terms of Accounting Method (A Case Study of Sari)

\begin{tabular}{|c|c|c|}
\hline & & $\begin{array}{l}\text { Teachers Often Do Not Have The Ability To Understand Our } \\
\text { Problems. }\end{array}$ \\
\hline & \multirow{6}{*}{$\begin{array}{lll}\text { Attachment } & \text { To } & \text { The } \\
\text { Parents } & & \end{array}$} & I Have A Lot Of Respect For My Parents. \\
\hline & & I Share My Problems With My Parents. \\
\hline & & I Trust My Parents Completely. \\
\hline & & My Parents Are Expectant People. \\
\hline & & My Parents Often Interfere In My Private Affairs. \\
\hline & & My Parents Can Not Understand Me. \\
\hline & \multirow[t]{2}{*}{$\begin{array}{l}\text { Attachment To The } \\
\text { Friends }\end{array}$} & $\begin{array}{l}\text { I Attach Great Importance To Communicating With My Good } \\
\text { Friends. }\end{array}$ \\
\hline & & My Friends' Opinions Are Important To Me \\
\hline \multirow{2}{*}{$\begin{array}{l}\text { Commitment } \\
\text { To Future Goals }\end{array}$} & \multicolumn{2}{|c|}{ My Goal In Studying Is To Get To University. } \\
\hline & \multicolumn{2}{|c|}{ I Have Little Desire To Continue My Education. } \\
\hline \multirow{3}{*}{ Busy } & \multicolumn{2}{|c|}{ How Many Hours A Week Do You Participate In-Home Activities? } \\
\hline & \multicolumn{2}{|c|}{ How Many Hours Do You Spend On Extracurricular Activities During The Week? } \\
\hline & \multicolumn{2}{|c|}{ How Many Hours A Week Do You Exercise? } \\
\hline \multirow{2}{*}{ Believe } & \multicolumn{2}{|c|}{ I Have A Lot Of Respect For The Police. } \\
\hline & \multicolumn{2}{|c|}{ I Violate The Law Whenever My Interests Require It. } \\
\hline
\end{tabular}

Self-control is the degree to which a person controls the chances of delinquency. This variable has six dimensions: risk-taking, semantic or non-semantic reaction, perseverance, self-centeredness, the function of instantaneous desires and anger. Twelve items measure this variable. Shoplifting, car theft, etc.) are used, and eight items measure delinquency. This research is legally prohibited and committed by adolescents aged 12-18 years.

Table 2. Indicators of self-control and delinquency variables

\begin{tabular}{|c|c|c|}
\hline & Indicator & Item \\
\hline \multirow{12}{*}{ 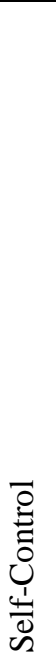 } & \multirow{3}{*}{ Angry } & I'll Get Mad Soon. \\
\hline & & When We Are Angry, No One Should Touch My Head. \\
\hline & & Getting Angry Is Not My Fault \\
\hline & \multirow{3}{*}{$\begin{array}{ll}\text { Citizenship } & \text { Of } \\
\text { Immediate } \\
\text { Desires }\end{array}$} & I'm More Concerned With What Happens To Me In The Short Term Than In The Long Term. \\
\hline & & I Often Act Without Prior Thought And Preparation. \\
\hline & & $\begin{array}{l}\text { I Mostly Do Things That Are Instantly Enjoyable, Even At The Cost Of Not Achieving Some } \\
\text { Long-Term Goals. }\end{array}$ \\
\hline & \multirow[t]{2}{*}{ Self-Cantered } & I Try To Get What I Want, Even If I Know It Will Cause Problems For Others. \\
\hline & & I Only Think Of Myself, Even If It Hurts Others. \\
\hline & \multirow[t]{2}{*}{ Risk-Taking } & Excitement And Adventure Are More Important To Me Than Security. \\
\hline & & $\begin{array}{l}\text { Sometimes I Do Some Things Even Though I Know They Are Problematic For Me, Just } \\
\text { Because Of The Excitement It Gives Me. }\end{array}$ \\
\hline & Perseverance & I Often Avoid Hard Work And Problems \\
\hline & $\begin{array}{l}\text { Linguistic } \\
\text { Reaction }\end{array}$ & In Most Cases, I Solve My Problems By Talking, And I Do Not See The Need To Use Force. \\
\hline \multirow{8}{*}{ 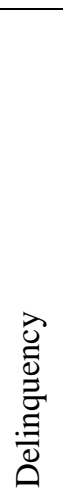 } & \multirow[t]{4}{*}{ Robber } & $\begin{array}{l}\text { Have You Ever Picked Up Something Of Less Value (Less Than } 2000 \text { Tomans Like A Book) } \\
\text { That Did Not Belong To You? }\end{array}$ \\
\hline & & $\begin{array}{l}\text { Have You Ever Taken Something Worth } 2 \text { to } 50 \text { Thousand Tomans That Did Not Belong To } \\
\text { You? }\end{array}$ \\
\hline & & $\begin{array}{l}\text { Have You Ever Taken Anything Worth More Than 50,000 Tomans That Did Not Belong To } \\
\text { You? }\end{array}$ \\
\hline & & Ever Had To Pay For A Movie, A Taxi, A Computer, Or Something? \\
\hline & \multirow[t]{3}{*}{ Violence } & Have You Ever Taken Money From Someone By Threat Or Force? \\
\hline & & How Much Is It Appreciated To Beat Or Injure A Family Member? \\
\hline & & Ever Beaten Or Injured Others? \\
\hline & Destruction & How Often Did You Ruin Someone Else's Property And Furniture? \\
\hline
\end{tabular}


The Role of Psychology Prevention in Controlling Student Victimization in Terms of Accounting Method (A Case Study of Sari)

Instrumental validation confirmed by factor analysis three instrumental validation based on instrumental validation the factor analysis of the restraint variable is 0.70 , which is at an acceptable level. (KMO) and indicates that the data have the necessary capability for factor analysis. The significance of the Bartlett test is 0.001 , which shows the fit of factor analysis the observed variables can measure the desired factor well and are generalizable.

Table 3. Rotated matrix of self-control components

\begin{tabular}{|c|c|c|c|c|c|c|c|}
\hline \multirow[t]{2}{*}{ No. } & \multirow[t]{2}{*}{ Observed Variables } & \multicolumn{6}{|c|}{ Variables } \\
\hline & & Angry1 & Self-Centeredness2 & To Be Instantaneous 3 & Risk-Taking4 & Perseverance5 & Linguistic 6 \\
\hline 1 & Get Everything & & 0.88 & & & & \\
\hline 2 & $\begin{array}{l}\text { To Be Thinking Of } \\
\text { Oneself }\end{array}$ & & 0.90 & & & & \\
\hline 3 & Going Crazy & 0.74 & & & & & \\
\hline 4 & Head To Head & 0.79 & & & & & \\
\hline 5 & Getting Angry & 0.81 & & & & & \\
\hline 6 & $\begin{array}{l}\text { Worried About The } \\
\text { Short Term }\end{array}$ & & & 0.78 & & & \\
\hline 7 & Without Thought & & & 0.67 & & & \\
\hline 8 & Instant Pleasure & & & 0.62 & & & \\
\hline 9 & Adventure & & & & 0.84 & & \\
\hline 10 & Excitement & & & & 0.84 & & \\
\hline 11 & Avoid Hard Work & & & & & 0.92 & \\
\hline 12 & Linguistic & & & & & & 0.93 \\
\hline
\end{tabular}

The KMO value of the social bond variable is 0.71 . Bartlett test also shows significance at the level of 0.01 .

Table 4. Rotating matrix of social bond components

\begin{tabular}{|c|c|c|c|c|c|c|c|c|}
\hline \multirow[t]{2}{*}{ no. } & \multirow[t]{2}{*}{ Observed variables } & \multicolumn{7}{|l|}{ Variables } \\
\hline & & $\begin{array}{l}\text { Attachment } \\
\text { to the teacher }\end{array}$ & $\begin{array}{l}\text { Communication } \\
\text { with parents }\end{array}$ & Belief & $\begin{array}{l}\text { Evaluation } \\
\text { from } \\
\text { parents }\end{array}$ & obligation & $\begin{array}{l}\text { Attachment to } \\
\text { friends }\end{array}$ & Work \\
\hline 1 & $\begin{array}{l}\text { Consult with the } \\
\text { teacher }\end{array}$ & 0.65 & & & & & & \\
\hline 2 & Teacher's opinion & 0.67 & & & & & & \\
\hline 3 & $\begin{array}{ll}\text { Lack } & \text { of } \\
\text { understanding } & \\
\text { teacher } & \end{array}$ & 0.64 & & & & & & \\
\hline 4 & Respect for parents & & 0.72 & & & & & \\
\hline 5 & Talk to parents & & 0.63 & & & & & \\
\hline 6 & Trust in parents & & 0.65 & & & & & \\
\hline 7 & families' exception & & & & 0.65 & & & \\
\hline 8 & $\begin{array}{l}\text { Involvement of } \\
\text { parents }\end{array}$ & & & & 0.75 & & & \\
\hline 9 & $\begin{array}{ll}\text { Lack } & \text { of } \\
\text { understanding } & \text { of } \\
\text { parents } & \end{array}$ & & & & 0.61 & & & \\
\hline 10 & Connect with friends & & & & & & 0.82 & \\
\hline 11 & Friends' comments & & & & & & 0.75 & \\
\hline 12 & $\begin{array}{l}\text { Concerning the } \\
\text { police }\end{array}$ & & & 0.53 & & & & \\
\hline 13 & Wrong deeds & & & 0.83 & & & & \\
\hline 14 & $\begin{array}{l}\text { Failure to comply } \\
\text { with the law }\end{array}$ & & & 0.83 & & & & \\
\hline 15 & $\begin{array}{ll}\text { Getting } & \text { to } \\
\text { university. } & \end{array}$ & & & & & 0.81 & & \\
\hline
\end{tabular}


The Role of Psychology Prevention in Controlling Student Victimization in Terms of Accounting Method (A Case Study of Sari)

\begin{tabular}{|l|l|l|l|l|l|l|l|l|}
\hline 16 & Education & & & & & 0.72 & & \\
\hline 17 & $\begin{array}{l}\text { Participate in-home } \\
\text { activities }\end{array}$ & & & & & & 0.73 \\
\hline 18 & $\begin{array}{l}\text { Participate in school } \\
\text { activities }\end{array}$ & & & & & & 0.40 \\
\hline 19 & $\begin{array}{l}\text { Participation in } \\
\text { sports activities }\end{array}$ & & & & & & 0.73 \\
\hline
\end{tabular}

Youth delinquency has been studied as a dependent variable in three dimensions: theft, violence, and destruction. The amount of its $\mathrm{KMO}$ is equal to 0.77 , and its Bartlett test is significant at the level of 0.01 .

Table 5. Rotating matrix of delinquent components

\begin{tabular}{|l|l|l|l|l|}
\hline No. & Observed Variables & \multicolumn{3}{l|}{ Variables } \\
\cline { 3 - 5 } & & Robber & Violence & Destruction \\
\hline 1 & Robber 1 & 0.51 & & \\
\hline 2 & Robber 2 & 0.55 & & \\
\hline 3 & Robber 3 & 0.76 & & \\
\hline 4 & Robber 4 & 0.79 & & \\
\hline 5 & Extortion & & 0.57 & \\
\hline 6 & Beating Family Members & & 0.84 & \\
\hline 7 & Beating Others & & 0.87 & \\
\hline 8 & Destroying Other People's Equipment & & & 0.55 \\
\hline
\end{tabular}

Indicators have the necessary reliability. Cronbach's alpha has been used except for two cases (commitment and engagement) in determining reliability. These two options were not included in the regression equation.

Table 6. Reliability coefficient of indicators

\begin{tabular}{|l|l|}
\hline Indicators & Alpha Value \\
\hline Self-Control & 0.73 \\
\hline Attachment & 0.65 \\
\hline Belief & 0.68 \\
\hline Obligation & 0.53 \\
\hline Work & 0.38 \\
\hline Social Bond 69 & 0.69 \\
\hline Delinquency & 0.71 \\
\hline
\end{tabular}

\section{DESCRIPTIVE FINDINGS}

Descriptive findings of independent variables based on Table 7 indicate that $39.3 \%$ of high school students in Sari have moderate self-control.

$30.1 \%$ of the respondents have overestimated their level of self-control. This variable, formed from six dimensions, has a significant effect on youth delinquency and is considered the most important independent variable. Student attachment is regarded as one of the dimensions of social bonding in control theory, and this research has been studied in three dimensions. Findings based on the Likert scale indicate that $47.2 \%$ of the respondents are moderately attached to the teacher. Evidence shows that $40 \%$ of students have a high attachment to their parents and most of them (i.e. 52.6) have a very high attachment to their friends. A comparison of adolescents 'attachment to friends with their attachment to parents shows that adolescents' attachment to friends is $28 \%$ more likely to have a high attachment to their parents, and their low attachment to a friend is less than their low attachment to a parent. Indicates the high attachment of adolescents in Sari to their peers. Frequency distribution of commitment variable to future goals as one of the dimensions of bond

The society obtained by combining the two items of desire to continue education and go to university shows that $64.4 \%$ of students are committed to their long-term goals. After that, high commitment has the highest share with $21 \%$. If we add these two floors together, the number 4.85 is obtained, which shows the high commitment of students towards their future goals. Only one percent of respondents have very little commitment to plans. Employment is one of the dimensions of social bonding, which consists of engaging in-home activities, extracurricular activities, and sports. $65.4 \%$ of students have a minimal occupation. $23 \%$ have a low 

Study of Sari)

level of involvement. In total, $88.4 \%$ of their employment is very low. Only $0.12 \%$ of students are too busy, not indicating a planned life. Belief rate is a variable made up of a combination of three items (belief in police, law and correctness). One of the dimensions of social bonding shows the highest percentage in the middle class, with a value of $33.8 \% .32 .8 \%$ of the respondents have a high level of belief. The lowest rate is related to the very low confidence levelof $3 \%$ of the sample size.

Table 7. Frequency distribution of independent variables

\begin{tabular}{|l|l|l|l|l|l|l|l|}
\hline & $\begin{array}{l}\text { Very } \\
\text { Low }\end{array}$ & Little & Medium & Very & $\begin{array}{l}\text { Very } \\
\text { Much }\end{array}$ & Missing & Whole \\
\hline You Have Self-Control & 2.7 & 18.8 & 3.9. & 30.1 & 7.4 & - & 100 \\
\hline Attachment To The Teacher & 2.2 & 1.8 & 47.2 & 31.8 & 4 & - & 100 \\
\hline Attachment To Parents & 2 & 9.6 & 24 & 40 & 24.4 & - & 100 \\
\hline Attachment To Friends & 0.2 & 0.5 & 6.96 & 39.8 & 52.6 & - & 100 \\
\hline Commitment To Future Goals & 1 & 1.7 & 11.9 & 21 & 64.6 & - & 100 \\
\hline Work & 65.4 & 23 & 5.2 & 0.5 & 0.7 & 5.2 & 100 \\
\hline Believe & 3 & 12.3 & 33.8 & 32.8 & 18 & - & 100 \\
\hline
\end{tabular}

Youth delinquency is limited as a variable related to the three dimensions of theft, vandalism and violence. Percentage distribution of theft (based on Table 8) shows that $43.7 \%$ of the city's students Sari has not committed any theft in the last two years. $45.2 \%$ have reported theft once, and $9.6 \%$ have mentioned it twice. The percentage distribution of violence also indicates that $22.7 \%$ to none title did not commit violence. 35.9\% said they had experienced violence once. 26.7 Percentage of violence against family members or others twice in the last two years. One of the dimension's delinquency is the destruction of the property of others. $31.1 \%$ of respondents said no equipment they have not ruined others in the last two years. $21.2 \%$ of the respondents have been destroyed once. $18.3 \%$ twice, and $21.5 \%$ have committed this act four or more times. According to the average of destruction (1.67), theft (0.69) and Violence (1.28), it can be said that destruction is in the first place, violence is in the second place, and theft is in the third place takes.

Table 8. Frequency distribution of dependent variables

\begin{tabular}{|l|l|l|l|l|l|l|l|}
\hline Frequency of Delinquency & Not At All & Once & Twice & Three Times & $\begin{array}{l}\text { Four Times And } \\
\text { More }\end{array}$ & $\begin{array}{l}\text { Missing } \\
\text { All }\end{array}$ & \begin{tabular}{l} 
Whole \\
\hline The Thief
\end{tabular} \\
\hline Destruction & 43.7 & 45.2 & 9.6 & 0.7 & 0.7 & - & 100 \\
\hline Violence & 31.1 & 21.2 & 18.3 & 7.7 & 21.5 & 0.2 & 100 \\
\hline
\end{tabular}

\section{ANALYSIS OF FINDINGS}

First, analyse the findings in the form of two-variable relationships. To show the relationships of two variables in the template, twodimensional tables of the level of variables have been reduced to the sequential level (low, medium, high). It should be noted Pearson correlation values are reported based on raw (unrated) data of variables. Also, the pattern of path or multivariate relations or the main hypotheses of the research will be discussed. The data indicate that the relationship between the self-control of high school students in Sari and their delinquency rate is significant at the level of 0.01. For the negative association and its severity based on Pearson statistics - 0.429. By increasing students' restraint, their delinquency rate decreases or decreases. In self-control, their delinquency increases. The data in Table 9 show that $90.5 \%$ of those with strong self-control had fewer offences. Although only $8 \%$ of those have poor self-control, they have expressed a lot of delinquency, but with the decrease of self-control, the rate of delinquency moderate $(50 \%)$ and those with strong self-control; did not have many crimes. Even their average delinquency was $9.5 \%$ - besides, $18 \%$ of school students' delinquency changes. The independent variable of restraint explains sari secondary school.

Table 9. Delinquency in terms of self-control

\begin{tabular}{|l|l|l|l|l|}
\hline Self-Control Delinquency & Week & Medium & Strong & Sum \\
\hline Low & $42.00 \%$ & $68.40 \%$ & $90.50 \%$ & $\begin{array}{l}280 \\
70.4 \%\end{array}$ \\
\hline
\end{tabular}


The Role of Psychology Prevention in Controlling Student Victimization in Terms of Accounting Method (A Case Study of Sari)

\begin{tabular}{|l|l|l|l|l|}
\hline Medium & $50.00 \%$ & $28.50 \%$ & $9.50 \%$ & $\begin{array}{l}106 \\
26.6 \%\end{array}$ \\
\hline High & $8.00 \%$ & $3.20 \%$ & $0.00 \%$ & $\begin{array}{l}12 \\
3 \%\end{array}$ \\
\hline Sum & & & & $\begin{array}{l}398 \\
\end{array}$ \\
& 50 & 253 & 95 & $100 \%$ \\
\hline
\end{tabular}

The second hypothesis of the research is an inverse relationship between social bonds and delinquency of Sari students. To test this hypothesis, the variables of occupation and commitment did not have the necessary reliability of the dimensions. The four social bonds are eliminated, and the social bond variable is formed from two dimensions of belief and attachment. According to Table 10, $56.2 \%$ of poor social ties have reported moderate delinquency. As the social bond of students increases, the average crime rate decreases, and delinquency is low. $90.4 \%$ of students who are highly connected, their delinquency is low.The intensity of the relationship between these two variables based on the Pearson test is -0.431 . This hypothesis is a $99 \%$ reliable generalization to the statistical community. Findings show a $10 \%$ increase in correlation between the new social link variable and indicates delinquency.

Table 10. Crime based on social connection

\begin{tabular}{|l|l|l|l|l|}
\hline Social Bond Delinquency & Week & Medium & Strong & Sum \\
\hline Low & $35.60 \%$ & $71.60 \%$ & $90.40 \%$ & $\begin{array}{l}285 \\
70.4 \%\end{array}$ \\
\hline Medium & $56.20 \%$ & $25.70 \%$ & $9.60 \%$ & $\begin{array}{l}108 \\
26.7 \%\end{array}$ \\
\hline High & $8.20 \%$ & $2.80 \%$ & $0.00 \%$ & $\begin{array}{l}12 \\
3 \%\end{array}$ \\
\hline Sum & 73 & $\begin{array}{l}218 \\
100 \%\end{array}$ & $\begin{array}{l}114 \\
100 \%\end{array}$ & $\begin{array}{l}405 \\
100 \%\end{array}$ \\
\hline
\end{tabular}

The third hypothesis is a positive relationship between students' self-control and their social connection. Evidence experimentally, there is a significant relationship between these two variables. The relationship between the two is substantial at the error level of 0.01 . The direction of the positive relationship and its intensity is relatively strong. Table 11 shows $46 \%$ of adolescents with poor self-control have poor social bonds. $60.1 \%$ of students who have moderate self-control, their bond is moderate, and $58.9 \%$ of those who have strong self-control have expressed that their bond is vital. Comparing these three numbers indicates that increasing selfcontrol also increases social bonding. Only $4 \%$ of people have poor self-control, and their bond is strong. A total of $30 \%$ of students' social bond changes as a variable vision Nose is explained by the independent variable of restraint.

Table 11. Social bonding based on self-control

\begin{tabular}{|l|l|l|l|l|}
\hline $\begin{array}{l}\text { Self-Control } \\
\text { Social Bond }\end{array}$ & Week & Medium & Strong & Sum \\
\hline Low & $46.00 \%$ & $18.20 \%$ & $2.10 \%$ & $\begin{array}{l}71 \\
17.8 \%\end{array}$ \\
\hline Medium & $50.00 \%$ & $60.10 \%$ & $38.90 \%$ & $\begin{array}{l}214 \\
53.8 \%\end{array}$ \\
\hline High & $4.00 \%$ & $21.70 \%$ & $58.90 \%$ & $\begin{array}{l}113 \\
28.4 \%\end{array}$ \\
\hline Sum & 50 & 253 & 95 & 398 \\
& $100 \%$ & $100 \%$ & $100 \%$ & $100 \%$ \\
\hline
\end{tabular}

\section{REGRESSION ANALYSIS}

In the previous sections, the relationship between the variables was examined in pairs and the first, second and third hypotheses were the basis of the Pearson test was confirmed. But in this part, regression is used. Using Regression, the effect of independent variables on the dependent variable is examined simultaneously. It should be noted that background variables of this research (such as parents' education, student age, father's job, family income, etc.) did not have a significant relationship with delinquency; they also did not enter the regression model. In the first model, self-control and social cohesion as independent variables and delinquency as a method-dependent variable enter the regression. In the first model, self-control and social bonds enter the equation. The regression table shows a significant inverse relationship between self-control and delinquency.There is also an inverse relationship 


\section{Study of Sari)}

between social linkage and delinquency, which is statistically significant. The beta coefficient self-control variable is one-tenth more than the social bond variable. Social bond variables based on two dimensions' attachment and belief, were built, and the dimensions of commitment and engagement were side-lined due to the poor reliability of social bonding were placed. In this model, about $24 \%$ of the dependent variable of the research is youth delinquency. In other words, $24 \%$ of delinquency of high school students in Sari by two variables, self-control and social bonding, can be explained, and the rest (76\%) pattern error or residual value, that is, other variables that are not included in the pattern. The standard equation for explaining delinquency is as follows is: (Social bond) - 0/27 (self-control) - $0.28=$ delinquency

Based on the amount of beta, the role of self-control in reducing delinquency is more significant than the social bond. The beta basis obtained for self-control, for one unit of change in the standard deviation of intelligence to the size of $-0.28 \%$ of youth delinquency changes. While per unit change in the standard deviation of social bond is $-0.27 \%$ change in delinquency.

Table 12. Bivariate regression model (self-control and social connection)

\begin{tabular}{|l|l|l|l|l|l|l|l|}
\hline \multirow{2}{*}{ Model 1 } & \multicolumn{2}{|l|}{ Non-Standard Coefficients } & $\begin{array}{l}\text { Standard Coefficients } \\
\text { Beta }\end{array}$ & T Value & Sig & R & R2 \\
\cline { 2 - 7 } & B & Standard Error & & & & \\
\hline Constant Number & 3.243 & 0.205 & & 15.812 & 0.00 & & \\
\hline Self-Control & -0.031 & 0.006 & -0.282 & -5.369 & 0.00 & 0.429 & 0.184 \\
\hline Social Bond & -0.153 & 0.03 & -0.271 & -5.165 & 0.00 & 0.486 & 0.236 \\
\hline
\end{tabular}

In the next stage, self-control and social connection variables entered regression, the first independent and the second dependent. According to Table 7, the third hypothesis, the relationship between self-control and social bond in error level 0.01 , is significant. This relationship is positive with the increase in self-control, so is the social bond increase and as it decreases, so does the bond. The beta coefficient of self-control relationship and social bond is equal to 0.545 . Indirectly between restraint and delinquency (through social link), there is an inverse relationship determined by multiplying the betas of the path.

Table 13: Univariate Regression Pattern (Self-Control)

\begin{tabular}{|l|l|l|l|l|l|l|l|}
\hline Model 2 & \multicolumn{2}{|l|}{$\begin{array}{l}\text { Non-Standard } \\
\text { Coefficients }\end{array}$} & $\begin{array}{l}\text { Standard } \\
\text { Coefficients } \\
\text { Beta }\end{array}$ & $\begin{array}{l}\text { T Value } \\
\text { Error }\end{array}$ & B Sig & R & R2 \\
\hline Constant Number & 2.828 & 0.318 & & 8.885 & 0.00 & & \\
\hline Self-Control & 0.106 & 0.008 & 0.545 & 12.946 & 0.00 & 0.545 & 0.297 \\
\hline
\end{tabular}

The path pattern shows that restraint is indirectly inversely related to delinquency. This relationship at the error level of 0.01 is significant, and its value is equal to the beta coefficient $(0.27 * 0.54)$. The effects of the variable of restraint on delinquency are equal to the sum of the direct and indirect effects with:

Indirect effect + direct effect $=$ total effect

Total effect $=-0.28+-0.14 / 5=42.5$

According to the regression tables, the three main hypotheses of the research are all confirmed.

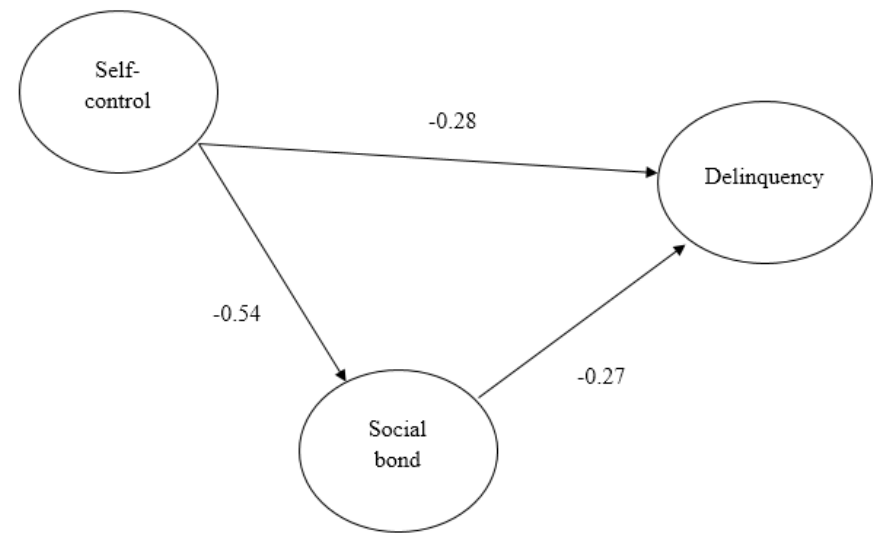




\section{The Role of Psychology Prevention in Controlling Student Victimization in Terms of Accounting Method (A Case Study of Sari)}

\section{CONCLUSION}

First, adolescents who have poor self-control in Sari have a high crime rate. These people seek immediate satisfaction and use easy methods to satisfy their desires. Some people have little stability, cannot plan, are self-centred, relative to others. They are indifferent and respond physically to contexts and situations. These people are mainly in answering questions they are not honest.

Second; Adolescents' self-control in Sari also indirectly affects their crime rate. This means those who have poor self-control, their social bond is also weak, and those who have a social bond.They are weak, and they have high delinquency. Therefore, self-control through the social link variable is also based on delinquency effects.

Third, the relationship between social bonds and delinquency is significant, and the study of social bonds shows its dimensions. There is an inverse relationship between the variables of belief and attachment of adolescents in Sari and their crime rate.

Fourth; From the dimensions of social bonding, "busyness" shows a fragile relationship with delinquency. Thisis probably due to the low reliability of adolescents' variable or unplanned life in Sari.But in studies conducted outside Iran, there is a strong relationship between adolescents' employment and their delinquency rate has been proven.

Fifth; Among the elements of the social bond, belief shows the strongest relationship with youth delinquency in Sari. But in a study conducted by Hirsch in the United States, attachment is the most effective social bond variableto explain delinquency.

Sixth; Adolescents' attachment to friends is more significant than their attachment to their parents and teachers. Teenagers attach great importance to communicating with their friends. Therefore, it is effect learning from friends can effectively explain delinquency. In other words, teenagers who have delinquent friends and their delinquency more.

Seventh; On the other hand, there is a significant relationship between the elements of the social bond, for example, those whose attachment the more they have, the more they believe in norms and laws.

Eighth; Two variables of self-control and social connection in $24 \%$ of youth delinquency (school students explains Sari. The findings clearly show the claims of those who say that control causes crime cannot be a valid claim. This theory is used to explain delinquency in Sari; other approaches are more appropriate. Its comprehensiveness can be claimed by examining it empirically in other cities as well evaluated.

\section{SUGGESTIONS}

First, since official statistics in Iran are not very significant, one of the ways to study delinquency referral to youth both delinquent (who are being rehabilitated in correctional facilities) and non-delinquent. Students can be reviewed by the self-reported survey method; it is suggested that they do similar research with this method.

Second: To achieve significant and credible results, one must gain the respondent's trust, including critics. In this type of study, respondents usually do not answer questions honestly because they feel threatened, especially if it is a serious crime. The researcher can talk and convince respondents and draw their attention to the importance of research can gain confidence and use by teachers or students who have influence and credibility among students. Another way to get the correct answers is to use questions and statements that make the crime seem ordinary enough so the respondent feels less threatened.

Third; Early socialization, which occurs in the family and the early years of life, plays an essential role in everyone's future. People who have gone through the proper socialization process in adolescence simply do not surrender to delinquency. Therefore, educating families to monitor students' behaviour can be effective. For example, families can monitor their student's movements in their leisure time, complete various programs and increase their social skills. This can be self-control strengthen adolescents and their relationship with society.

Fourth; Strengthening and supporting the family and society of youth delinquents can help reconstruct social life and prevent reoffending has a positive effect. Families need to deal appropriately with teens; for example, punishing a teenager for a minor offence would severely affect their self-control. Therefore, it is suggested that families and community members allow adolescents to compensate and deal with them without treatingthem as sick people.

Fifth; The school's contribution to adolescent socialization should not be overlooked. Adolescents in a favourable environment, the school, is active and has a good relationship with the teacher and their classmates, and he is less prone to delinquency. Educate teachers to deal appropriately with adolescents and establish an intimate relationship with them so that adolescents can easily share their problems with teachers.

\section{REFERENCES}

1) Besemer, S., et al., A systematic review and meta-analysis of the intergenerational transmission of criminal behaviour. Aggression and Violent Behavior, 2017. 37: p. 161-178.

2) Simmons, C., et al., The differential influence of absent and harsh fathers on juvenile delinquency. Journal of adolescence, 2018. 62: p. 9-17.

3) NgaI, M.M., Gini Sikes's ethnographic 8 Ball Chicks: A Year in the Violent World of Girl Gangsters. More recently, she has figured in scholarly monographs Monica Brown's Gang Nation: Delinquent Citizens in Puerto Rican, Chicano, and 
Chicana Narratives and Marie "Keta" Miranda's Homegirls in the Public Sphere. These. THE WOMAN INTHE ZOOT SUIT: p. 137.

4) Boucherf, K. and M. Omrane, 2 Researching Youth Street Groups in Algeria: Between the Universal and the Particular. Beyond Marginalization: Youth Street Groups in Northern Africa: p. 26.

5) Katz, M.B., Introduction: The urban" underclass" as a metaphor of social transformation, in The" Underclass" Debate. 2018, Princeton University Press. p. 1-24.

6) Hirtenlehner, H. and S. Schulz, Deterrence and the Moral Context: Is the Impact of Perceived Sanction Risk Dependent on Best Friends' Moral Beliefs? Criminal Justice Review, 2021. 46(1): p. 53-79.

7) Bind, R.H. et al., Mother-infant interaction in women with depression in pregnancy and women with a history of depression: the Psychiatry Research and Motherhood-Depression (PRAM-D) study. BJPsych Open, 2021. 7(3).

8) Bellair, P.E., V.J. Roscigno, and M.B. Velez, Occupational Structure, Social Learning, and Adolescent Violence 1, in Social learning theory and the explanation of crime. 2017, Routledge. p. 197-225.

9) Larsson, O.L., Technocracy, Governmentality, and Post-Structuralism. Critical Review, 2020: p. 1-21.

10) Boucher, J.M., Autism spectrum disorder: Characteristics, causes and practical issues. 2017: SAGE.

11) Young, J., 2. Realist Research as a Basis for Local Criminal Justice Policy, in Realist Criminology. 2019, University of Toronto Press. p. 33-72.

12) Nam, H.H., et al., Amygdala structure and the tendency to regard the social system as legitimate and desirable. Nature Human Behaviour, 2018. 2(2): p. 133-138.

13) Khan, N., et al., Effects of Social Stigma on the Sick People of Covid-2019 in the Community of the World. Available at SSRN 3600579, 2020.

14) Pennington, A. and J. Stanford, The Future of Work for Australian Graduates. 2019, Canberra: Australia Institute.

15) Makhurane, F., Promoting the rehabilitation of juvenile offenders in selected South African correctional schools: a wellness perspective. 2019.

16) Freeman, C.P., The Human-Animal Earthling Identity: Shared Values Unifying Human Rights, Animal Rights, and Environmental Movements. 2020: University of Georgia Press.

17) Hirsch, R.M. and J.R. Slack, A nonparametric trend test for seasonal data with serial dependence. Water Resources Research, 1984. 20(6): p. 727-732.

18) Wilcox, P., K.C. Land, and S.A. Hunt, Criminal circumstance: A dynamic multicontextual criminal opportunity theory. 2018: Routledge.

19) Gottfredson, M.R. and T. Hirschi, A general theory of crime. 1990: Stanford University Press.

20) Singh, I., A disorder of anger and aggression: children's perspectives on attention-deficit/hyperactivity disorder in the UK. Social science \& medicine, 2011. 73(6): p. 889-896.

21) Hirschi, T. and M. Gottfredson, Commentary: Testing the general theory of crime. Journal of research in crime and delinquency, 1993. 30(1): p. 47-54. 